УДК 66.08:631.53.027

ИЗУЧЕНИЕ ФИЗИКО-ХИМИЧЕСКИХ СВОЙСТВ И БИОАКТИВНОСТИ

РАЗБАВЛЕННЫХ ВОДНЫХ РАСТВОРОВ НИТРИТ-ИОНОВ

ПОСЛЕ ИХ ЭЛЕКТРООБРАБОТКИ В НЕПРОТОЧНОМ

ДИАФРАГМЕННОМ ЭЛЕКТРОЛИЗЕРЕ И ИХ ВЛИЯНИЯ

НА ПРОРАЩИВАНИЕ СЕМЯН С ОБРАЗОВАНИЕМ ЗЕЛЕНЫХ

КОРМОВЫХ ДОБАВОК

\title{
THE STUDY OF PHYSICO-CHEMICAL PROPERTIES AND BIOACTIVITY DILUTE AQUEOUS SOLUTIONS OF NITRITE-IONS AFTER THEIR ELECTRICAL TREATMENT IN THE NON-FLOWING \\ A DIAPHRAGM CELL AND THEIR INFLUENCE ON SEED GERMINATION WITH THE FORMATION OF GREEN FEED ADDITIVES
}

${ }^{1}$ Осадченко И.М., доктор химических наук
${ }^{1,2}$ Горлов И.Ф., доктор сельскохозяйственных наук, профессор, академик РАН

${ }^{1}$ Харченко О.В., кандидат сельскохозяйственных наук

${ }^{1}$ Николаев Д.В., доктор сельскохозяйственных наук

${ }^{1}$ Osadchenko I.M., doctor of chemical sciences, professor

${ }^{1,2}$ Gorlov I.F., doctor of agricultural sciences, professor, academician of RAS

${ }^{1}$ Kharchenko $\boldsymbol{O}$.V., candidate of agricultural sciences

${ }^{I}$ Nikolaev D.V., doctor of agricultural sciences

${ }^{1}$ Поволжский научно-исследовательский институт производства и переработки мясомолочной продукции, Волгоград

${ }^{2}$ Волгоградский государственный технический университет

${ }^{1}$ Volga region research institute of manufacture and processing of meat-and-milk production, Volgograd

${ }^{2}$ Volgograd state technical university

В статье приводятся результаты изучения влияния процесса электроактивации водных растворов католита и анолита с применением нитрита натрия с концентрацией $0,5 \Gamma /$ дм$^{3}\left(\mathrm{NO}_{2}^{-} 0,33 \Gamma_{\text {д }}^{-} \mathrm{m}^{3}\right)$ на эффективность процесса проращивания семян ячменя, озимой пшеницы и яровой пшеницы. При этом выявлены физико-химические свойства водных растворов нитрит-ионов и электрообработанныХ растворов, доказана биологическая активность ЭХО растворов на процесс проращивания семян, а также установлены параметры ЭХО в электролизере с диафрагмой в непроточном режиме.

The article presents the results of studying of the process of electric activation of aqueous solutions of anolyte and catholyte with the use of sodium nitrite with a concentration of $0.5 \mathrm{~g} / \mathrm{dm}^{3}\left(\mathrm{NO}_{2}-0.33 \mathrm{~g} / \mathrm{dm}^{3}\right)$ on the efficiency of the process of germination of seeds of barley, winter wheat and spring wheat. At the same time re- 
vealed the physico-chemical properties of aqueous solutions of nitrite ions and electrically operated solutions, proved biological activity of the ECHO solution on the germination process of seeds, and the settings are set to ECHO in the cell with the diaphragm in non-flowing mode.

Ключевые слова: электролизер, электрохимическая обработка, анолит, католит, растворы, нитрит-ионы, энергия прорастания, семена, ячмень, озимая и яровая пшеница.

Keywords: electrolyzer, electrochemical treatment, anolyte, catholyte, solution, nitrite ions, germination energy, seeds, barley, winter and spring wheat.

Введение. Изучение причин неравновесного состояния и биологической активности водных растворов, полученных в диафрагменном электролизере, осложняется многокомпонентностью их состава.

В литературе содержатся данные по электрохимической обработке (электрообработке, активации) водных растворов (в основном содержащих хлориды с концентрацией солей $0,01-0,1$ моль/дм $\left.{ }^{3}\right)[1,2,3]$.

Достоинством таких способов является снижение затрат на материалы (ресурсосбережение), повышение экологической безопасности при их применении. Образующийся при электрохимической обработке (ЭХО) щелочной католит обладает восстановительными свойствами и кислотный анолит - окислительными свойствами [3].

Как правило, католит и анолит используют для очистки сточных вод, дезинфекции оборудования и помещений в сельском хозяйстве.

Учитывая большой объем публикаций по ЭХО водных растворов неорганических солей, стоит заметить относительно малый объем данных по растворам солей щелочных металлов и азотистой кислоты.

Между тем нитрит-ионы в виде солей натрия встречаются в природных, сточных водах животноводческих ферм и пищевой промышленности, в кормах и отходах производств [4]. мами [4].

Нитрит-ионы образуются при восстановлении нитратов микроорганиз-

Нитрит-ионы токсичны (в несколько раз токсичнее нитрат-ионов), их предельно допустимая концентрация в водопроводной воде составляет 3,0 мг/дм ${ }^{3}[5]$.

В организме теплокровных животных нитриты образуют метгемоглобин, с аминами - нитрозамины, вызывающие заболевания.

В то же время нитрит натрия применяют в качестве цветостабилизатора при производстве мясопродуктов.

Исходя из вышеизложенного, актуальность в изучении физикохимических свойств нитрит-ионов, например, в виде нитрита натрия не вызывает сомнений. 
Цель работы - изучение физико-химических свойств и биоактивности нитрит-ионов в разбавленных водных растворах после их ЭХО и их влияния на проращивание семян с образованием зеленых кормовых добавок.

Материал и методика исследований. В качестве объекта изучения использовали нитрит-натрия («Х-ч.»).

Согласно литературным данным [6], содержание нитрит-ионов в сточных водах не превышает 1000 мг/дм³.

ЭХО проводили на установке (приборе) типа «МЕЛЕСТА» (изготовитель ООО «МЕЛЕСТА», г. УФА, 2011 г.).

Установка включала электролизер вертикального типа из пищевой пластмассы общим объемом около 1 дм $^{3}$ и выпрямитель [7]. Прибор был нами усовершенствован для обеспечения наблюдений, контроля параметров путем замены крышки и выпрямителя другого типа (BCA-5к). Катод изготовлен из нержавеющей стали, анод - типа ОРТА (окиснотитанорутениевый анод), площадь поверхности каждого электрода $-5 \mathrm{~cm}^{2}$. В качестве диафрагмы использовали брезент из пластмассовой ткани.

Соотношение объемов католит:анолит 2:1 (660:330 $\left.\mathrm{cm}^{3}\right)$. Малый объем представляет собой съемный стакан с диафрагмой.

Измерение активной кислотности (pH) и окислительновосстановительного потенциала (ОВП, мВ) относительно хлорсеребряного электрода для сравнения проводили с помощью иономера «Нитрон» (Россия).

Растворы готовили по навеске $\mathrm{NaNO}_{2}$ растворением в мерной колбе.

Концентрацию нитрит-ионов и продуктов их превращений определяли согласно методам неорганической химии [8].

Испытания на биоактивность проводили путем предварительного замачивания (3-4 часа) семян зерновых культур и проращивания во влажном состоянии согласно требованиям ГОСТ 12038-84 (приведены средние данные при двух повторениях).

Результаты и их обсуждение. Предварительными опытами было установлено, что ЭХО растворов нитрит-ионов стабильно проводили при концентрации до 0,4 г/дм ${ }^{3}$, при напряжении $42 \mathrm{~B}$, при температуре $20-25^{\circ} \mathrm{C}$ в течение 30-35 минут (без охлаждения).

Оптимальные условия ЭХО: сила тока - 0,2-0,3А (плотность тока на электродах 0,04-0,06А/см²), объем католита $-660 \mathrm{~cm}^{3}$, а анолита - $330 \mathrm{~cm}^{3}$.

Использовали водный раствор нитрит натрия с концентрацией 0,5 г/дм ${ }^{3}$ $\left(\mathrm{NO}_{2}^{-} 0,33\right.$ г/дм $\left.{ }^{3}\right)$.

Характеристики полученных католита и анолита приведены в таблице 1.

Таблица 1 - Характеристики полученных католита и анолита

\begin{tabular}{|l|c|c|}
\hline \multicolumn{1}{|c|}{ Раствор } & $\mathrm{pH}$ & OВП, $\mathrm{MB}$ \\
\hline Исходный раствор & 5,4 & +256 \\
\hline Католит & 12,7 & -243 \\
\hline Анолит & 2,4 & +50 \\
\hline
\end{tabular}

В согласии с данными литературы, а также нами экспериментально установлено: повышение $\mathrm{pH}$ и снижение ОВП католита связаны с переносом катио- 
нов в катодную камеру и насыщением раствора водородом, а снижение $\mathrm{pH}$ и повышение ОВП анолита обусловлено подкислением раствора и образованием окислителей типа атомарного кислорода, $\mathrm{OH}^{-}$радикалов и т.п. Кроме того, изменения $\mathrm{pH}$ и ОВП ЭХО растворов связаны со структурно-энергетическими изменениями молекул растворителя (воды) [12]. В католите обнаружено наличие $\mathrm{NH}_{3}$ при электровосстановлении $\mathrm{NO}_{2}^{-}$до $10 \%$ от их первоначального уровня в анолите - определено химанализом $\mathrm{NO}_{3}-$ ионы при электроокислении $\mathrm{NO}_{2}^{-}$ (до $5 \%$ от исходного уровня).

Электрообработанные растворы испытывали на биоактивность путем замачивания в течение 3-4 часов [3] и проращивания семян зерновых культур по ГОСТ $12038-84$ в бумажном рулоне при $18-20^{\circ} \mathrm{C}$ (в темноте).

Результаты испытаний на биоактивность представлены в таблицах 2-4 соответственно по энергии прорастания (\% проросших семян от общего количества на 3-й день) - всхожесть (\% проросших семян от общего количества на 7-й день) и морфологические показатели (на 7-й день прорастания).

Таблица 2 - Энергия прорастания, \%

\begin{tabular}{|l|c|c|c|}
\hline \multirow{2}{*}{$\begin{array}{c}\text { Раствор } \\
\text { замачивания }\end{array}$} & \multicolumn{3}{|c|}{ Вид семян } \\
\cline { 2 - 4 } & ячмень & яровая пшеница & Озимая пшеница \\
\hline Католит & 60 & 55 & 58 \\
\hline Анолит & 53 & 56 & 50 \\
\hline Вода (контроль) & 68 & 70 & 60 \\
\hline
\end{tabular}

Как видно из таблицы 2, стимуляция проращивания не обнаружена; наибольшие значения замедления проращивания семян: в католите с яровой пшеницей $-15 \%$, в анолите с ячменем $-15 \%$, в анолите с яровой пшеницей $-10 \%$.

Таблица 3 - Всхожесть, \%

\begin{tabular}{|l|c|c|c|}
\hline \multirow{2}{*}{$\begin{array}{c}\text { Раствор } \\
\text { замачивания }\end{array}$} & \multicolumn{3}{|c|}{ Вид семян } \\
\cline { 2 - 4 } & ячмень & яровая пшеница & озимая пшеница \\
\hline Католит & 78 & 70 & 70 \\
\hline Анолит & 75 & 72 & 64 \\
\hline Вода (контроль) & 80 & 83 & 76 \\
\hline
\end{tabular}

Как видно из данных таблицы 3 , стимуляция проращивания семян не обнаружена; наибольшее значение замедления проращивания семян: в анолите с яровой пшеницей $-11 \%$, в анолите с озимой пшеницей $-12 \%$, в анолите с ячменем $-5 \%$.

Таблица 4 - Морфологические показатели, мм

\begin{tabular}{|l|l|c|c|c|}
\hline \multirow{2}{*}{\multicolumn{2}{|c|}{ Раствор замачивания }} & \multicolumn{3}{|c|}{ Вид семян } \\
\cline { 3 - 5 } \multicolumn{2}{|c|}{} & ячмень & яровая пшеница & $\begin{array}{c}\text { озимая пше- } \\
\text { ница }\end{array}$ \\
\hline Католит & корни & 65,8 & 55,0 & 65,8 \\
& проростки & 116,7 & 95,3 & 104,7 \\
\hline Анолит & корни & 50,5 & 60,0 & 36,6 \\
& проростки & 93,5 & 102,6 & 47,6 \\
\hline Вода (контроль) & корни & 98,6 & 69,6 & 72,0 \\
& проростки & 113,4 & 112,4 & 104,2 \\
\hline
\end{tabular}


Как видно из таблицы 4, стимуляция проращивания обнаружена в относительно малой степени; наибольшие значения замедления проращивания семян: в анолите с яровой пшеницей (корни) - 13,7\%, в анолите с ячменем (корни) $-48,8 \%$, в анолите с озимой пшеницей (проростки) $-54,3 \%$.

О механизме действия ЭХО растворов в соответствии с литературными данными можно предположить следующее. Учитывая тот факт, что замедление процесса проращивания семян зерновых культур связано с использованием анолитов, можно высказать предположение, что в составе анолитов находятся активные частицы оксидантов (атомы кислорода, радикалы гидрооксила и т.п.), которые ингибируют этот процесс за счет снижения активности ферментных систем семян зерновых фуражных культур, что может быть полезным при посеве яровой пшеницы в подзимний период для выращивания ее весной в засушливое время, как это описано в патенте [9].

Заключение. Изучены физико-химические свойства - $\mathrm{pH}$ и ОВП исходных водных растворов нитрит-ионов и электрообработанных растворов - католита и анолита. Выявлена биологическая активность анолита ЭХО растворов на семенах ячменя, яровой и озимой пшеницы в форме замедления проращивания их семян. Определены параметры ЭХО в электролизере с диафрагмой в непроточном режиме.

\section{Библиографический список}

1. Кирпичников, П.А. О природе электрохимической активации сред / П.А. Кирпичников, В.М. Бахир, П.У. Гамер [и др.] // Доклады АН СССР. 1986. - Т. 286, № 3. - С. 663-667.

2. Прилуцкий, В.М. Электрохимически активированная вода: аномальные свойства, механизм биологического действия / В.М. Прилуцкий, В.М. Бахир. M., 1997. -228 c.

3. Осадченко, И.М. Разработка технологии получения электроактивированной воды, водных растворов и их применение в АПК / И.М. Осадченко, И.Ф. Горлов. - Волгоград, 2010. - 92 с.

4. Краткая химическая энциклопедия. - Т.3. - М., 1964. - С. 497.

5. СаНПин 2.1.4.559-96 Питьевая вода. Гигиенические требования к качеству воды централизованных систем питьевого водоснабжения. Контроль качества.

6. Халемский, В.М. Решение проблем очистки воды / В.М. Халемский, Э.М. Швец, В.И. Орехова // Цветная металлургия. - 2014. - № 2. - С. 60-61.

7. Прибор для получения католита и анолита «МЕЛЕСТА» (г. Уфа, ООО «МЕЛЕСТА», 2011 г.).

8. Шарло, Г. Методы неорганической химии. Количественный анализ неорганических соединений / Г. Шарло. - М., 1965. - С. 552-554.

9. Патент № 2124838, РФ А 01 № 37/00; опубл. 1999. 